\title{
Turizm Rehberliği Alanındaki Lisansüstü Tezlerin Bibliyometrik Çerçevesi ${ }^{1}$ \\ (Araştırma/Düzeltme Makalesi)
}

Bibliometric Framework of Postgraduate Theses in Tourism Guidance

Doi: 10.29023/alanyaakademik.868763

\section{Burhanettin ZENGIN}

Prof. Dr. Sakarya Uygulamalı Bilimler Üniversitesi, Turizm Fakültesi, Turizm Rehberliği, bzengin@subu.edu.tr

Orcid No: 0000-0002-6368-0969

\section{Burak ATASOY}

Araştırma Görevlisi, Sakarya Uygulamalı Bilimler Üniversitesi, Turizm Fakültesi, Turizm

Rehberliği,

burakatasoy@subu.edu.tr

Orcid No: 0000-0002-9742-8112

Bu makaleye atıfta bulunmak için: Zengin, B., \& Atasoy, B. (2021). Turizm Rehberliği Alanındaki Lisansüstü Tezlerin Bibliyometrik Çerçevesi. Alanya Akademik Bakış, 5(1), 143-160.

\begin{abstract}
Anahtar kelimeler:
Turizm Rehberliği,

Turist Rehberliği,

Profesyonel Turist

Rehberliği,

Lisansüstü Rehberlik

Tezleri
\end{abstract}

Makale Geliş Tarihi:

11.03.2020

Kabul Tarihi:

08.09.2020

\section{Keywords:}

Tourism Guidance, Tourist Guidance,

Professional Tourist

Guidance, Graduate

Guidance Theses

\section{ÖZET}

Turizm rehberliği toplumlararası kültür aktarımını sağlayan ve mesleği icra edenlerin kültür elçisi olarak ifade edildiği bir alandır. Destinasyonlara yönelik turizm hareketlerinin yaklaşık 1.5 milyar katılımcıya ulaşması, turizm rehberlerine olan ihtiyacı arttırmıştır. Ortaya çıkan profesyonel turist rehberi ihtiyacl ise Türkiye'de kurslar, ön lisans, lisans ve lisansüstü programlar yardımıyla karşılanmaktadır. Bu kapsamda araştırma, turizm rehberliği konulu lisansüstü tezlerim geçmiş ve mevcut durumunun incelenmesi amacıyla gerçekleştirilmiştir. Yüksek Öğretim Kurumu Tez Merkezi (YÖKTEZ), veri tabaninda yer alan turizm rehberliği ile ilgili konular üzerinde yapılan lisansüstü tezlerin bibliyometrik analizi gerçekleştirilmiştir. Araştırmada tarama modeli esas alınarak 1989-2019 yılları arasında yapılmış 87 lisansüstü teze ulaşılmıştır. Araştırma kapsamında elde edilen veriler çeşitli parametreler ışlğında yorumlama ve değerlendirme süreçlerine tabi tutulmuştur. Sonuçlar turizm rehberliği alanında 2015 yılı sonrası lisansüstü eğitimde bir artış ve ilk kez Turizm Rehberliği Anabilim Dalında yayımlanan lisansüstü çalışmaların olduğunu göstermektedir.

\section{ABSTRACT}

Tourism guidance is an area in which the cultural transfer of societies and those who perform the profession are expressed as cultural ambassadors. The fact that the tourism movements towards destinations reached to 1.5 billion participants increased the need for tourism guidance. At this point, countries aim to train qualified tourism guides in order to achieve the objectives such as efficiency and efficiency in tourism marketing by providing more tourist satisfaction. The resulting need for pre-professional 
tourist guide license in Turkey are solved with the help of undergraduate and graduate programs. This research was conducted in order to examine the past and present status of graduate studies on tourism guidance and the research was conducted by choosing qualitative study method. In this context, bibliometric analysis of graduate theses on tourism guidance subjects in the database of Higher Education Institution Thesis Center (YÖKTEZ) was performed. In the research, 87 graduate theses were reached based on the screening model. The data obtained within the scope of the research were subjected to interpretation and evaluation processes in the light of various parameters. The results show that there is an increase in postgraduate education in the field of tourism guidance and postgraduate studies published in the Department of Tourism Guidance for the first time.

${ }^{1}$ Prof. Dr. Burhanettin Zengin ve Araştırma Görevlisi Burak Atasoy tarafindan gerçekleştirilen "Turizm Rehberliği Alanindaki Lisansüstü Tezlerin Bibliyometrik Çerçevesi" isimli makale, Alanya Akademik Bakış dergisi 2020 yll 4. cilt, 3. saylst 975-992 sayfa aralığında yayımlanmış olup, makalenin kaynakça bölümünde sehven yapılan bir hata tespit edilmesi nedeni ile "düzeltme makalesi" olarak 2021 yll 5. cilt, 1. saylst 143-160 sayfa aralığında tekrar yayımlanmıştır. Yapılan bu küçük düzeltme makalenin akademik içeriğini etkilememektedir.

\section{GİRIŞ}

Teknolojik gelişmeler, arttan değişim ve rahatlama isteği, ekonomik anlamda ülke ve bireylerde oluşan refah artışı insanların daha sık seyahat etmesine neden olan unsurlar arasında yer almaktadır (Çokal ve Aslan 2016: 54). Son yıllardaki bu gelişmeler turizmi birçok açıdan etkilemiş̧tir. Uluslararası seyahat katılımcılarında görülen nicel anlamda artış turist rehberliği mesleğine olan ihtiyacın daha fazla hissedilmesine neden olmuştur. Öte yandan milletlerin ve turizm bölgelerinin tanıtım elçileri olan turist rehberlerine, turizm hareketleri doğrultusunda daha çok ihtiyaç duyulması mesleğe olan ilginin de artmasına katk1 sağlamıştır (Sert ve Karacaoğlu 2018: 81). Turizm hareketleri başladığı dönemden bu yana değişerek alternatif turizm türleri olarak karşımıza çıksa da turist rehberlerine olan ihtiyaç halen söz konusu olmaktadır (Çokal ve Aslan 2016: 53).

Rekabetin sert ve yıkıcı etkileri olan turizm endüstrisinde tercih edilebilirliğini arttırmak isteyen ülkeler turist memnuniyetinin bu problemi çözmek için kilit unsur olduğunu düşünmektedir. Ancak turist istek ve beklentilerinin farklılaşması turist memnuniyetini de zorlaştırmaktadır (Güllü ve Atasoy 2019: 799). Bu kapsamda çoğu ülke hizmet kalitesine yönelmektedir. Özellikle destinasyonların elçileri diyebileceğimiz turist rehberlerinin ülkeyi ve destinasyonu daha iyi tanıtması, ziyaretçilerin tatil memnuniyetini ve destinasyon sadakatini doğrudan etkilemektedir (Yenipinar ve Zorkiriş̧̧i 2013: 112). Çünkü yerli veya yabancı ziyaretçilere, bölge veya ulusun sahip olduğu doğal, tarihi, kültürel mirası tanıtma görevinin yanı sıra gezi sırasında ziyaretçiler ile yerel halk arasında kurulan iletişimde de rehberlerin yönetici görevi bulunmaktadır (Yenipınar, Bak ve Çapar, 2014: 87). Bu yönüyle turist rehberlerinin ulusal ve bölgesel çerçevede turizmin gelişmesinde kilit bir rol oynadığ söylenebilir (Bayram ve Zengin 2017: 197).

Turist rehberlerinin destinasyonların pazarlanması sürecinde ve turistlerin tatil deneyimlerinde memnuniyet oluşturacak role sahip olması turizm açısından farklı bir yerde 144 
değerlendirilmesine olanak sağlamaktadır (Eker, Kaya ve Zengin 2019: 88). Benzer şekilde Cohen (1985), gerçek turist rehberlerinin bilinen bir çevreden uzak olan turistlere verdiği bilgiler, turistik yerlerdeki yönlendirmeler ile yaptığı liderlik ve seyahat esnasında paylaştığ tecrübeler ile turizmdeki önemini vurgulamaktadır. Bu kapsamda turizm rehberlerinin ziyaretçi kabul eden ulus ve gönderen ülkeler arasında kurulan köprüyü temsil ettiği söylenebilir. Gezi veya tur öncesi ve sonrası hemen her konuda turistin iletişim halinde olabileceği turist rehberleri turist memnuniyetinin sağlanmasında önemli bir yere sahiptir.

Turizmde böylesine önemli bir sorumluluğu üstlenmesi turist rehberlerinin, akademinin de yakın takibine girmesine olanak sağlamıştır. Bu kapsamda ön lisans, lisans ve yüksek lisans düzeyinde eğitimi verilen turizm rehberliği alanında son dönemlerde çeşitli çalışmalar gerçekleştirilmiştir (Yenipınar vd. 2014; Çetin ve Kızılırmak, 2017). Bu çalışmada ise Ulusal Tez Merkezi veri tabanında yer alan turist rehberliği alanındaki lisansüstü çalışmaların bibliyometrik çerçevede incelenmesi hedeflenmektedir. Bu kapsamda, turizm rehberliği alanının gelişim sürecinin ve alana yönelik çalışmaların kavramsal olarak incelenmesi ve bu doğrultuda daha sonra gerçekleştirilecek çalışmalara 1ş1k tutacak bir kaynak oluşturulması amaçlanmaktadır. Böylelikle lisansüstü tezlerin hangi konular üzerinde ve ne zaman yoğunlaştığı, geçmiş ve günümüz arasında farklılık olup olmadığının bilinmesi önem arz etmektedir.

\section{ALANYAZIN İNCELEMESI}

Araştırmanın bu bölümde turizm ve turizm rehberliği alanlarının birbiriyle olan ilişkisi vurgulanmış, lisansüstü turizm rehberliği ile ilgili alanlarda gerçekleştirilen çalışmalardan bahsedilmiş ve turizm rehberliği alanındaki mevcut bibliyometrik çalışmalar ele alınmıştır.

\subsection{Turizm Rehberliği Mesleği}

Günümüz turisti daha sorgulayıcı ve araştırmacı olarak karşımıza çıkmaktadır. Uluslararası turizm hareketlerine katılan ziyaretçiler, bilgiye artık daha rahat ulaşmakta ve elde ettiği bilgiyi sorgulayabilmektedir. Turistlerin seyahatleri süresince bilgi elde etmek istemesi, alanında uzman kişilere yani rehberlere olan ihtiyacı arttırmaktadır. Dünya Turist Rehberliği Birliği Federasyonu tarafından turist rehberi, bölgeye gelen ziyaretçileri kendi seçmiş oldukları dilde yönlendiren, kültürel ve doğal miras gibi çeşitli konularda sahip olduğu bilgiyi yorumlayan kişi şeklinde bahsedilmektedir (WFTGA, 2003). Başka bir anlatımda turist rehberi, seyahat edilen ülkeyi temsil eden ve bölge imajını oluşturan model ve büyükelçi şeklinde ifade edilmektedir (Eker vd. 2019: 60). Ayrıca turist rehberleri, turistler ile ev sahibi toplumlar arasındaki kurulan etkileşimi kontrol etmek ve yetkililer tarafindan belirlenen bilgiyi turistlere vermek gibi önemli sorumluluklara sahiptir (Reisinger ve Steiner 2006: 484).

Çokal ve Aslan (2016: 54), ülkelerin tarihi ve kültürel değerlerini en iyi şekilde anlatan ve karşısındakini bilgilendiren kişilerden profesyonel turist rehberi şeklinde bahsetmektedir. Başka bir anlatımda Türkiye Turist Rehberleri Birliği (2014), yerli veya yabancı ziyaretçilerin önceden seçmiş oldukları dili kullanarak ülkenin sahip olduğu kültür, turizm, tarih, çevre, doğa veya benzeri değerleri ile varlıklarını kültür ve turizm politikaları doğrultusunda tanıtan kişilerden profesyonel turist rehberi şeklinde bahsetmektedir. Bu açıdan bakıldığında, turist rehberlerinin yerli veya yabancı ziyaretçiye belirli bir dil kullanarak herhangi bir turizm değerine ilişkin bilgi verdiği ve bu süreci yönetirken bazı ulusal değerleri gözetmek durumunda olduğu söylenebilir. 
Turistler, tatil süreçleri içerisinde katılmış oldukları turistik aktivitelerden mümkün olduğu kadar memnun olmak istemektedir. Şüphesiz burada sahip olduğu bilgiyle öne çıkan turist rehberleri bu süreçleri yöneten kültür elçileri olarak önemli bir sorumluluğa sahiptir (Kaya ve Özhan 2012: 110). Önceden planlanan turların başlangıç ve bitimine kadar geçen sürede turistlere liderlik eden turist rehberleri turun başarı veya kalitesi üzerinde doğrudan bir etkiye sahiptir (Zengin ve Eker 2016: 2). Öte yandan günümüz turist profili artık bilgiyi kolayca elde etmekte ve yanı sıra elde ettiği bilgiyi sorgulamaktadır. Turist açısından söz konusu olan bu değişiklikler, turizm endüstrisi içerisinde hizmet veren profesyonellerden biri olan turist rehberlerini de doğrudan etkilemiştir (Olcay vd. 2014: 350). Benzer şekilde hem bilgili turist profiline sahip katılımcıların sayısındaki radikal artış hem de teknoloji ile bilgiye erişimin son derece etkin ve hızlı olması turist rehberlerini, kendilerini geliştirmek durumunda bırakmıştır (Çakmak ve Demirkol 2017: 222). Devletler ise sağladıkları eğitim ve sertifika programlarıyla turizm rehberlerinin kişisel gelişimiyle yakından ilgilenmektedir (Lovrentjev 2015: 555). Bu noktada turist rehberlerinin sahip oldukları bilgi, deneyim, tecrübe ve yetenekleri doğrultusunda mesleklerini icra ederken ulusal değerleri göz önünde bulundurması, inovasyanlara açık olması, iletişim kabiliyetlerinin gelişmiş ve tarafsız olması turist memnuniyetini arttıracaktır. Böylelikle üstlendikleri bu sorumlulukla turist rehberlerinin ikame ettikleri ülkelerin turizmine pozitif katkı sağlayacağı söylenebilir.

\subsection{Turizm Rehberliği Alanında Bibliyometrik Araştırmalar}

Alanyazın incelendiğinde görülmektedir ki, çeşitli anabilim dallarında turizm üzerine yapılmış bibliyometrik çalışmalar mevcuttur (Sarışık ve Özbay 2015; Çapar, Toksöz ve Dönmez 2018; Akkaşoğlu vd. 2019). Bibliyometrik çalışmalar söz konusu bilim alanlarında mevcut durumu ortaya koymak ve belirli süreç içerisindeki gelişimi göstermek adına gerçekleştirilmiş hem yazın hem de araştırmacılar için önemli araştırmalar şeklinde düşünülebilir.

Araştırma kapsamında çalışmanın odak noktası düşünülerek gerçekleştirilen alanyazın taraması sonucu turizm veya turist rehberliği alanında yapılan üç bibliyometrik çalışmaya rastlanmıştır. $\mathrm{Bu}$ durum turizm yazının oldukça çok sayıda bibliyometrik araştırmaya konu olmasına rağmen turizm rehberliği alanının daha az sayıda bibliyometrik çalışmanın gerçekleştirildiğini göstermektedir. Şahin ve Acun (2015), 1990-2015 yılları arasında gerçekleştirilen ulusal turizm kongresi bildiri kitaplarında yer alan 860 bildiriden turist rehberliği konulu 22 bildirinin bibliyometrik analizini gerçekleştirmişlerdir. Yazarlar bildirileri sayfa aralığı, sayfa sayıları yoğunluğu, yazar sayısı, çalışılan kurum, bildiri konusu ve anahtar kelime gibi ölçütlerde değerlendirmişlerdir.

Çapar, Toksöz ve Dönmez (2018), yılında gerçekleştirdikleri araştırma ile turizm rehberliği yazınında bir başka bibliyometrik çalışmayı yapmıştır. Buna göre yazarlar, Yükseköğretim Kurumu Ulusal Tez Merkezi veri tabanından erişim sağladığı 2005-2007 yıllarına ait 40 tezi, ProQuest veri tabanına 2005-2017 y1llarına ait 51 yabancı tezi, ulusal 32 uluslararası 71 turizm rehberliğine ilişkin makaleyi, Ulusal Turizm Kongrelerine ait 29 ve Lisansüstü Turizm Öğrencileri Araştırma Kongresine ait rehberlik alanına ilişkin 12 bildiriyi incelemişlerdir. Yazarlar değerlendirme parametrelerini konu başlı̆̆ı, yazar, yıl, ulusal, uluslararası, en fazla yayınlayan dergi, yayın yapan öğretim elemanı sayısı ve yıllara göre dağılım gibi ölçütler şeklinde belirtmektedir. 
Özsoy ve Çokal (2018), katıldıkları bir kongrede Yükseköğretim Kurumu Ulusal Tez Merkezi veri tabanında 1989-2018 yıllarına ait turist rehberliği alanında 77 lisansüstü tezin bibliyometrik analizinden bahsetmişlerdir. Yazarlar bu kapsamda 61 yüksek lisans tezi ve 16 doktora tezi incelemişlerdir. Yazarlar lisansüstü tezleri, tezlerin türü, yıllar içerisindeki dağılımı, enstitü, anabilim dalı, danışman dağılımı, danışman ünvanı, anahtar kelime, veri toplama teknikleri, kullanılan yöntem gibi ölçütleri kullanarak değerlendirme yapmışlardır.

Kısacası, turizm yazını incelendiğinde bibliyometrik çalışmaların günden güne arttığ1 görülmektedir. Turizm pazarlaması (Özel ve Kozak 2012), gastronomi turizmi (Sarışık ve Özbay 2015), sürdürülebilir turizm (Demirbulat ve Dinç 2017) gibi konularda bibliyometrik çalışmaların olduğu bilinmektedir. Ancak turizm rehberliği yazınının diğer turizm alanlarına göre nispeten daha az olduğu söylenebilir. Özellikle turizm rehberi ihtiyacı ve buna bağlı olarak lisans \& lisansüstü eğitim kurumlarının sayısının artmış olması akademik yazında daha fazla turizm rehberliği konularında çalışmalar olacağına ipucu vermektedir. Bu noktada turizm rehberliğine ilişkin lisansüstü çalışmaların incelenmesi, akademik camianın alana olan ilgisinin ne ölçüde olduğunu da ortaya koyacaktır.

Tablo 1. 1989-2019 Yılları Arasında Yayınlanan Lisansüstü Tezler

\begin{tabular}{|c|c|c|c|}
\hline Yazar & Tez Başlığı & Kurum & Yıl \\
\hline Bilge & Profesyonel Turist Rehberliği & $\begin{array}{l}\text { İstanbul } \\
\text { Üniversitesi }\end{array}$ & 1989 \\
\hline Değirmencioğlu & Türkiye'de Turizm Rehberliği Eğitimine Bir Yaklaşım & $\begin{array}{c}\text { Gazi } \\
\text { Üniversitesi }\end{array}$ & 1998 \\
\hline Polat & $\begin{array}{l}\text { Seyahat İşletmelerinde, Profesyonel Turist Rehberliği, } \\
\text { Rehberlik Mesleğinin Sorunları ve Çözüm Önerileri } \\
\text { Üzerine Bir Alan Araştırması }\end{array}$ & $\begin{array}{l}\text { Anadolu } \\
\text { Üniversitesi }\end{array}$ & 2001 \\
\hline Tangüler & $\begin{array}{l}\text { Profesyonel Turist Rehberliği ve Profesyonel Turist } \\
\text { Rehberlerinin Seyahat Acentası ve Müşteri İlişkileri } \\
\text { (Kapadokya Örneği) }\end{array}$ & $\begin{array}{l}\text { Hacettepe } \\
\text { Üniversitesi }\end{array}$ & 2002 \\
\hline Ridgeway & $\begin{array}{l}\text { Turist Rehberi Kelime Haznesinin Okuma Parçaları ile } \\
\text { Geliştirilmesi }\end{array}$ & $\begin{array}{l}\text { Hacettepe } \\
\text { Üniversitesi }\end{array}$ & 2003 \\
\hline Çeşmeci & $\begin{array}{l}\text { Türkiye'de Paket Turların Yönetiminde Turist } \\
\text { Rehberlerinin Fonksiyonu: Yönetsel Rollerin Tespiti, } \\
\text { Sorunlar ve Çözüm Önerileri }\end{array}$ & $\begin{array}{l}\text { Erciyes } \\
\text { Üniversitesi }\end{array}$ & 2004 \\
\hline Ekmekçi & $\begin{array}{l}\text { Paket Turların Sürdürülebilirliğinde Turist Rehberlerinin } \\
\text { Rolü }\end{array}$ & $\begin{array}{l}\text { Sakarya } \\
\text { Üniversitesi }\end{array}$ & 2005 \\
\hline Temizkan & Turist Rehberlerinin Türkiye İmajını Algılamaları & $\begin{array}{l}\text { Mustafa } \\
\text { Kemal } \\
\text { Üniversitesi }\end{array}$ & 2005 \\
\hline Akbulut & $\begin{array}{l}\text { Ege Bölgesindeki Profesyonel Turist Rehberlerinin } \\
\text { Mesleki Sorunları ve Çözüm Önerilerine Yönelik Bir } \\
\text { Araştırma }\end{array}$ & $\begin{array}{l}\text { Akdeniz } \\
\text { Üniversitesi }\end{array}$ & 2006 \\
\hline Ege & $\begin{array}{l}\text { Kars Meslek Yüksek Okulu Turizm Rehberliği } \\
\text { Programında İngilizce Öğrenimi Gören Öğrencilerin } \\
\text { Program Geliștirmeye Yönelik İhtiyaç Analizi }\end{array}$ & $\begin{array}{l}\text { Kafkas } \\
\text { Üniversitesi }\end{array}$ & 2006 \\
\hline
\end{tabular}




\begin{tabular}{|c|c|c|c|}
\hline Tetik & $\begin{array}{l}\text { Türkiye'de Profesyonel Turist Rehberliği ve Müşterilerin } \\
\text { Turist Rehberlerinden Beklentilerinin Analizi (Kuşadası } \\
\text { Örneği) }\end{array}$ & $\begin{array}{l}\text { Balıkesir } \\
\text { Üniversitesi }\end{array}$ & 2006 \\
\hline Sar1 & $\begin{array}{l}\text { Müzelerde Tur Rehberi Olarak Kullanılabilecek Otonom } \\
\text { Hareketli Bir Robot Tasarımı ve Benzetimi }\end{array}$ & $\begin{array}{l}\text { Boğaziçi } \\
\text { Üniversitesi }\end{array}$ & 2006 \\
\hline Öter & $\begin{array}{l}\text { Seyahat Acentelerinde Pazarlama Bilgi Sistemlerine Turist } \\
\text { Rehberlerinin Katkıları: Ege Bölgesi Örneği }\end{array}$ & $\begin{array}{l}\text { Dokuz Eylül } \\
\text { Üniversitesi }\end{array}$ & 2007 \\
\hline Güzel & $\begin{array}{l}\text { Türkiye İmajının Geliştirilmesinde Profesyonel Turist } \\
\text { Rehberlerinin Rolü (Alman Turistler Üzerine Bir } \\
\text { Araştırma) }\end{array}$ & $\begin{array}{l}\text { Balıkesir } \\
\text { Üniversitesi }\end{array}$ & 2007 \\
\hline Demircan & Vergi Hukuku Açısından Profesyonel Turist Rehberliği & $\begin{array}{l}\text { Anadolu } \\
\text { Üniversitesi }\end{array}$ & 2007 \\
\hline Güneş & $\begin{array}{l}\text { Eski Yunan ve Roma Mitolojisinin İngilizce Mesleki } \\
\text { Yabancı Dil Derslerinde Materyal Olarak Kullanımı (S.Ü. } \\
\text { Beyşehir Meslek Yüksekokulu Turizm Rehberliği } \\
\text { Programı Örneği) }\end{array}$ & $\begin{array}{c}\text { Selçuk } \\
\text { Üniversitesi }\end{array}$ & 2008 \\
\hline Temizkan & $\begin{array}{l}\text { Profesyonel Turist Rehberlerinin Turizm } \\
\text { Pazarlamasındaki Rolüne Etkisi Açısından Hizmetiçi } \\
\text { Eğitim Seminerleri }\end{array}$ & $\begin{array}{c}\text { Gazi } \\
\text { Üniversitesi }\end{array}$ & 2010 \\
\hline Çakır & $\begin{array}{l}\text { Profesyonel Turist Rehberlerinin Çalışma Biçimi ve } \\
\text { Mesleki Eğitim Süreleri ile İş Tatminleri Arasındaki İlişki }\end{array}$ & $\begin{array}{c}\text { Atatürk } \\
\text { Üniversitesi }\end{array}$ & 2010 \\
\hline Müküs & $\begin{array}{l}\text { Doğu Anadolu Bölgesi'nde Çalışan Turist Rehberlerinin } \\
\text { Yeterliliği ve Turist Memnuniyetinin Analizi }\end{array}$ & $\begin{array}{l}\text { Yüzüncü Y11 } \\
\text { Üniversitesi }\end{array}$ & 2010 \\
\hline Arslantürk & $\begin{array}{l}\text { Yükseköğretim Düzeyinde Turist Rehberliği Eğitimi } \\
\text { Veren Öğretim Kurumlarında Uygulanan Eğitime Yönelik } \\
\text { Öğrenci Algılamaları }\end{array}$ & $\begin{array}{c}\text { Gazi } \\
\text { Üniversitesi }\end{array}$ & 2010 \\
\hline Toker & $\begin{array}{l}\text { Kültür Turizminin Sürdürülebilirliğinde Profesyonel } \\
\text { Turist Rehberlerinin Rolü: Ankara Örneği }\end{array}$ & $\begin{array}{l}\text { Anadolu } \\
\text { Üniversitesi }\end{array}$ & 2011 \\
\hline Tetik & $\begin{array}{l}\text { Turist Rehberlerinin Ekoturizm Alanındaki Yeterlilikleri: } \\
\text { Doğu Karadeniz Örneği }\end{array}$ & $\begin{array}{l}\text { Balıkesir } \\
\text { Üniversitesi }\end{array}$ & 2012 \\
\hline Solmaz & $\begin{array}{l}\text { Turizm Politikalarının Oluşturulmasında Turist } \\
\text { Rehberlerinin Rolü }\end{array}$ & $\begin{array}{c}\text { Akdeniz } \\
\text { Üniversitesi }\end{array}$ & 2012 \\
\hline Şahin & $\begin{array}{l}\text { Turist Rehberlerinin Kültürlerarası İletişim Yeterlilikleri: } \\
\text { Alman, İngiliz ve Rus Turistlerin Algılamaları }\end{array}$ & $\begin{array}{l}\text { Balıkesir } \\
\text { Üniversitesi }\end{array}$ & 2012 \\
\hline Gül & $\begin{array}{l}\text { Türkiye'deki Turizm Rehberliği Öğretim Programlarının } \\
\text { Değerlendirilmesi }\end{array}$ & $\begin{array}{l}\text { Afyon } \\
\text { Kocatepe } \\
\text { Üniversitesi }\end{array}$ & 2012 \\
\hline Çiçek & $\begin{array}{l}\text { Profesyonel Turist Rehberlerinin Performans Kriterleri İle } \\
\text { Çalışma Koşulları Arasındaki İlişki: Antalya Örneği }\end{array}$ & $\begin{array}{c}\text { Akdeniz } \\
\text { Üniversitesi }\end{array}$ & 2013 \\
\hline Acar & $\begin{array}{l}\text { Profesyonel Turist Rehberlerinin Liderlik Yönelimleri: } \\
\text { Aydın Turist Rehberleri Odası'na Kayıtlı Olan Profesyonel } \\
\text { Turist Rehberleri Örneği }\end{array}$ & $\begin{array}{l}\text { Adnan } \\
\text { Menderes } \\
\text { Üniversitesi }\end{array}$ & 2014 \\
\hline
\end{tabular}




\begin{tabular}{|c|c|c|c|}
\hline Üner & $\begin{array}{l}\text { Turist Rehberlerinin Tükenmişlik Düzeylerinin } \\
\text { Belirlenmesi (Ankara Ölçeği) }\end{array}$ & $\begin{array}{c}\text { Gazi } \\
\text { Üniversitesi }\end{array}$ & 2015 \\
\hline Ünal & $\begin{array}{l}\text { Profesyonel Turist Rehberlerinin Mesleki Yeterliliklerinin } \\
\text { Turistlerin Destinasyon İmaj Algısı ve Genel } \\
\text { Memnuniyeti Üzerine Etkisi (Alman Turistlere Yönelik } \\
\text { Antalya Şehir Turunda Bir Uygulama) }\end{array}$ & $\begin{array}{l}\text { Akdeniz } \\
\text { Üniversitesi }\end{array}$ & 2015 \\
\hline Bak & $\begin{array}{l}\text { Turist Rehberlerinin Performansının Turist Tatminine } \\
\text { Etkisi: Kapadokya'yı Ziyaret Eden Yabancı Turistler } \\
\text { Üzerinde Bir Araştırma }\end{array}$ & $\begin{array}{l}\text { Mersin } \\
\text { Üniversitesi }\end{array}$ & 2015 \\
\hline Akköz & $\begin{array}{l}\text { Profesyonel Turist Rehberlerinin Sahip Olması Beklenen } \\
\text { Nitelikleri ile Sergiledikleri Performansın Yerli Turistler } \\
\text { Tarafindan Değerlendirilmesi }\end{array}$ & $\begin{array}{l}\text { Gaziantep } \\
\text { Üniversitesi }\end{array}$ & 2015 \\
\hline Toksöz & Turist Rehberlerinin Meslek Etiği Algısının Ölçülmesi & $\begin{array}{l}\text { Mersin } \\
\text { Üniversitesi }\end{array}$ & 2015 \\
\hline $\mathrm{Ar}$ & $\begin{array}{l}\text { Somut Olmayan Kültürel Mirasın Korunmasında Turist } \\
\text { Rehberlerinin Rolü }\end{array}$ & $\begin{array}{l}\text { Balıkesir } \\
\text { Üniversitesi }\end{array}$ & 2015 \\
\hline Büyükkuru & $\begin{array}{l}\text { Turist Rehberlerinin İletişim Becerilerinin Turistlerin Tur } \\
\text { Deneyimi Üzerine Etkisi: Nevşehir İlinde Bir Araştırma }\end{array}$ & $\begin{array}{l}\text { Nevşehir Hacı } \\
\text { Bektaş Veli } \\
\text { Üniversitesi }\end{array}$ & 2015 \\
\hline Tokay & $\begin{array}{l}\text { Profesyonel Turist Rehberlerinin Türkiye İmajını } \\
\text { Algılamalarındaki Değişim }\end{array}$ & $\begin{array}{l}\text { Eskişehir } \\
\text { Osmangazi } \\
\text { Üniversitesi }\end{array}$ & 2015 \\
\hline Eker & $\begin{array}{l}\text { Profesyonel Turist Rehberleri Bakış Açısıyla Turizm } \\
\text { Rehberliği Eğitim Müfredatlarının Uygulama Yeterliliği }\end{array}$ & $\begin{array}{l}\text { Sakarya } \\
\text { Üniversitesi }\end{array}$ & 2015 \\
\hline Çetinkaya & $\begin{array}{l}\text { Rehberli Turlarda Tur Rehberlerinin Turist Memnuniyeti } \\
\text { Üzerinde Oynadığı Rol ve Bu Bağlamda Yeniden Ziyaret } \\
\text { Eğilimine Etkisi: İstanbul'da Bir Araştırma }\end{array}$ & $\begin{array}{l}\text { İzmir Katip } \\
\text { Çelebi } \\
\text { Üniversitesi }\end{array}$ & 2015 \\
\hline İrigüler & $\begin{array}{l}\text { Tur Rehberlerinin Duygusal Emek Kullanımı ile İş } \\
\text { Doyumu ve Tükenmişlik Düzeyleri Arasındaki İlişkiler } \\
\text { Üzerine Bir Araştırma: İzmir İli Örneği }\end{array}$ & $\begin{array}{l}\text { İzmir Katip } \\
\text { Çelebi } \\
\text { Üniversitesi }\end{array}$ & 2015 \\
\hline Asmadili & $\begin{array}{l}\text { Paket Turlarda Müşteri Memnuniyetini Arttırma Aracı } \\
\text { Olarak Algılanan Riskin Azaltılmasında Turist Rehberinin } \\
\text { Rolü }\end{array}$ & $\begin{array}{l}\text { Balıkesir } \\
\text { Üniversitesi }\end{array}$ & 2015 \\
\hline Çokal & $\begin{array}{l}\text { Bir Kültür Elçisi Olarak Profesyonel Turist Rehberinin } \\
\text { Turistlere Aktarılan Kültürel Değerlere Katkısına Yönelik } \\
\text { Turist Algılamaları: Kapadokya Örneği }\end{array}$ & $\begin{array}{l}\text { Nevşehir Hacı } \\
\text { Bektaş Veli } \\
\text { Üniversitesi }\end{array}$ & 2015 \\
\hline Özdemir & Turist Deneyiminde Profesyonel Turist Rehberlerinin Rolü & $\begin{array}{l}\text { İstanbul } \\
\text { Üniversitesi }\end{array}$ & 2016 \\
\hline Gültekin & $\begin{array}{l}\text { Profesyonel Turist Rehberlerinin Duygusal Zeka Düzeyi } \\
\text { İle Problem Çözme Becerileri Arasındaki İlişkinin Günlük } \\
\text { Turlarda Karşılaştıkları Yönetsel Sorunlar Bazında } \\
\text { İncelenmesi }\end{array}$ & $\begin{array}{l}\text { Akdeniz } \\
\text { Üniversitesi }\end{array}$ & 2016 \\
\hline
\end{tabular}




\begin{tabular}{|c|c|c|c|}
\hline Çapar & $\begin{array}{l}\text { Kültürel ve Doğal Mirasın Sürdürülebilirliğinde Turist } \\
\text { Rehberlerinin Rolü: Kapadokya'yı Ziyaret Eden Yabancı } \\
\text { Turistler Üzerine Bir Araştırma }\end{array}$ & $\begin{array}{l}\text { Mersin } \\
\text { Üniversitesi }\end{array}$ & 2016 \\
\hline Kirıc1 & $\begin{array}{l}\text { Turist Rehberlerinin Tükenmişlik Düzeylerinin İşe } \\
\text { Yabancılaşma Eğilimlerine Etkisi }\end{array}$ & $\begin{array}{l}\text { Nevşehir Hacı } \\
\text { Bektaş Veli } \\
\text { Üniversitesi }\end{array}$ & 2016 \\
\hline Türkmen & $\begin{array}{l}\text { Turist Rehberlerinin Duygusal Zekâ Yetenekleri ile } \\
\text { Liderlik Davranışları Arasındaki İlişsinin Belirlenmesine } \\
\text { Yönelik Bir Araştırma }\end{array}$ & $\begin{array}{l}\text { Balıkesir } \\
\text { Üniversitesi }\end{array}$ & 2016 \\
\hline Acun & $\begin{array}{l}\text { İş Aile Çatışması ve Turist Rehberlerinin İşten Ayrılma } \\
\text { Niyetlerine Etkisi }\end{array}$ & $\begin{array}{l}\text { Balıkesir } \\
\text { Üniversitesi }\end{array}$ & 2016 \\
\hline Gökçe & $\begin{array}{l}\text { Lisans Düzeyinde Turizm Rehberliği Eğitimi Verilen } \\
\text { Üniversitelerde Sanat Tarihi Eğitiminin Mesleki Turizm } \\
\text { Eğitimindeki Yerine Yönelik Bir Değerlendirme }\end{array}$ & $\begin{array}{l}\text { Adnan } \\
\text { Menderes } \\
\text { Üniversitesi }\end{array}$ & 2016 \\
\hline Deveci & $\begin{array}{l}\text { Uluslararası Skal Ödülü "Turizm Eğitim Oscarı" Almış } \\
\text { Turizm Rehberliği Eğitimi Veren Yükseköğretim } \\
\text { Kurumlarının Hizmet Kalitesi Ölçümü: Turizm Rehberliği } \\
\text { Öğrencileri Üzerine Bir Araştırma }\end{array}$ & $\begin{array}{l}\text { Balıkesir } \\
\text { Üniversitesi }\end{array}$ & 2016 \\
\hline Düz & $\begin{array}{l}\text { Turist Rehberlerinin Performans Kriterlerini Belirlemeye } \\
\text { Yönelik Bir Çalışma: Turist Rehberliği Performans Ölçeği } \\
\text { Geliştirilmesi }\end{array}$ & $\begin{array}{l}\text { Anadolu } \\
\text { Üniversitesi }\end{array}$ & 2016 \\
\hline Kalyoncu & $\begin{array}{l}\text { Turist Rehberlerinin Paket Turlarda Kullandıkları İzlenim } \\
\text { Yönetimi Tekniklerinin Kişisel Etkileşim Kalitesi Üzerine } \\
\text { Etkisi }\end{array}$ & $\begin{array}{l}\text { Anadolu } \\
\text { Üniversitesi }\end{array}$ & 2017 \\
\hline Yetgin & $\begin{array}{l}\text { Turist Rehberlerinin Tükenmişlik ve Ekonomik Kaygı } \\
\text { Düzeylerinin Mesleki Bağlılık Düzeyleri Üzerindeki Etkisi }\end{array}$ & $\begin{array}{l}\text { Anadolu } \\
\text { Üniversitesi }\end{array}$ & 2017 \\
\hline Ünal & $\begin{array}{l}\text { Turist Rehberlerinin Duygusal Emek Düzeyi ve İşe } \\
\text { Yabancılaşmalarının Tükenmişlik Üzerine Etkisi }\end{array}$ & $\begin{array}{l}\text { Nevşehir Hacı } \\
\text { Bektaş Veli } \\
\text { Üniversitesi }\end{array}$ & 2017 \\
\hline Özoğul & $\begin{array}{l}\text { Profesyonel Turist Rehberlerinin Kişilik Özellikleri ile } \\
\text { Mesleki Bağl1lık Arasındaki İlişki Üzerine Psikolojik } \\
\text { Sermayenin Aracılık Etkisi }\end{array}$ & $\begin{array}{l}\text { Adnan } \\
\text { Menderes } \\
\text { Üniversitesi }\end{array}$ & 2017 \\
\hline Ulusoy & $\begin{array}{l}\text { Turist Rehberlerinin Kültürel Zekâ Düzeyi ve Özyeterlilik } \\
\text { İnançlarının Hizmet Sunumuna Etkisi }\end{array}$ & $\begin{array}{l}\text { Balıkesir } \\
\text { Üniversitesi }\end{array}$ & 2017 \\
\hline Eser & $\begin{array}{l}\text { Kişilik Özelliklerinin Mesleğe Yönelik Tutuma Etkisinde } \\
\text { Öğrenme Stilleri ve Akademik Motivasyonun Aracılık } \\
\text { Rolü: Lisans Turizm Rehberliği Öğrencileri Üzerine Bir } \\
\text { Araştırma }\end{array}$ & $\begin{array}{l}\text { Mersin } \\
\text { Üniversitesi }\end{array}$ & 2017 \\
\hline Dömbak & $\begin{array}{l}\text { İşletme Yeteneklerine Göre Rekabet Strateji ve } \\
\text { Davranışlarının Farklılaşması: Turist Rehberi Çalıştıran A } \\
\text { Grubu Seyahat Acentelerinde Bir Uygulama }\end{array}$ & $\begin{array}{l}\text { Atatürk } \\
\text { Üniversitesi }\end{array}$ & 2017 \\
\hline Cansu & $\begin{array}{l}\text { Profesyonel Turist Rehberlerinin Eğitim-Öğretim } \\
\text { Dönemlerinde Aldıkları Yabancı Dil Eğitiminin Mesleki } \\
\text { Açıdan Yeterliliği }\end{array}$ & $\begin{array}{l}\text { Kastamonu } \\
\text { Üniversitesi }\end{array}$ & 2018 \\
\hline
\end{tabular}




\begin{tabular}{|c|c|c|c|}
\hline Aysin & $\begin{array}{l}\text { Turist Rehberlerinin Duygusal Zekâ ile Rehberlik Stilleri } \\
\text { İlişkisi }\end{array}$ & $\begin{array}{c}\text { Ege } \\
\text { Üniversitesi }\end{array}$ & 2018 \\
\hline Özögütçü & $\begin{array}{l}\text { Turist Rehberlerinin Gastronomi Bilgisi ve Algısının } \\
\text { Tavsiye Niyetine Etkisi }\end{array}$ & $\begin{array}{l}\text { Kırklareli } \\
\text { Üniversitesi }\end{array}$ & 2018 \\
\hline Kazoğlu & $\begin{array}{l}\text { Toplum Temelli Turizm Yaklaşımı: Turist Rehberlerinin } \\
\text { Algılamaları Üzerine Bir Araşırma }\end{array}$ & $\begin{array}{l}\text { Balıkesir } \\
\text { Üniversitesi }\end{array}$ & 2018 \\
\hline Dumanlı & $\begin{array}{l}\text { Turist Rehberlerinin Stresle Başa Çıkma Tarzları ile } \\
\text { Mizah Tarzları Arasındaki İlişkinin Belirlenmesi }\end{array}$ & $\begin{array}{l}\text { Balıkesir } \\
\text { Üniversitesi }\end{array}$ & 2018 \\
\hline Akçaharman & $\begin{array}{l}\text { Turist Rehberlerinin Mesleki Sorunları ve Çözüm } \\
\text { Önerileri: İstanbul Örneği }\end{array}$ & $\begin{array}{l}\text { Balıkesir } \\
\text { Üniversitesi }\end{array}$ & 2018 \\
\hline Bozkurt & $\begin{array}{l}\text { Turist Rehberlerinin Performanslarının Turist } \\
\text { Memnuniyeti ve Turistlerin Alışveriş Davranışı Üzerine } \\
\text { Etkisi: Nevşehir İlinde Bir Uygulama }\end{array}$ & $\begin{array}{l}\text { Nevşehir Hacı } \\
\text { Bektaş Veli } \\
\text { Üniversitesi }\end{array}$ & 2018 \\
\hline Gürge & $\begin{array}{l}\text { Turist Rehberlerinin Yaşam Kalitesinin Türkiye'de } \\
\text { Rehberlik Mesleğinin Çalışma Koşulları Açısından } \\
\text { Değerlendirilmesi }\end{array}$ & $\begin{array}{l}\text { Anadolu } \\
\text { Üniversitesi }\end{array}$ & 2018 \\
\hline Genç & $\begin{array}{l}\text { Turist Rehberlerinin Yaşadıkları Zorlukların Kariyer } \\
\text { Bağlılığına Etkisi }\end{array}$ & $\begin{array}{l}\text { Mersin } \\
\text { Üniversitesi }\end{array}$ & 2018 \\
\hline Şalk & $\begin{array}{l}\text { Turist Rehberlerinin Artırılmış Gerçeklik Uygulamalarına } \\
\text { Yönelik Algılarının Belirlenmesi }\end{array}$ & $\begin{array}{l}\text { Balıkesir } \\
\text { Üniversitesi }\end{array}$ & 2018 \\
\hline Aksaray & $\begin{array}{l}\text { Turist Rehberlerinin Hizmet Kalitesinin Destinasyon } \\
\text { İmajina Etkisi }\end{array}$ & $\begin{array}{l}\text { Selçuk } \\
\text { Üniversitesi }\end{array}$ & 2018 \\
\hline Çınar & $\begin{array}{l}\text { Turizm Rehberliği Bölümü Öğrencilerinde Genel } \\
\text { Özyeterlilik Algısı, Mesleki Kaygı ve Mesleği Yapma } \\
\text { Niyeti İliş̧kisi }\end{array}$ & $\begin{array}{l}\text { Mersin } \\
\text { Üniversitesi }\end{array}$ & 2018 \\
\hline Kin & $\begin{array}{l}\text { Turistlerin Mobil Turist Rehberi Uygulamalarına İlişkin } \\
\text { Memnuniyetlerin Belirlenmesi: Muğla İlinde Bir } \\
\text { Uygulama }\end{array}$ & $\begin{array}{l}\text { Nevşehir Hacı } \\
\text { Bektaş Veli } \\
\text { Üniversitesi }\end{array}$ & 2018 \\
\hline Çorman & Turist Rehberliğinde Foodie Özelliğinin Önemi & $\begin{array}{l}\text { Balıkesir } \\
\text { Üniversitesi }\end{array}$ & 2018 \\
\hline Karakaş & $\begin{array}{l}\text { Turist Rehberlerinin Mesleki Sorun ve Çözüm Önerileri: } \\
\text { İstanbul Örneği }\end{array}$ & $\begin{array}{l}\text { Balıkesir } \\
\text { Üniversitesi }\end{array}$ & 2018 \\
\hline Altun & Tur Rehberlerinin Beden Dili ve Turist Deneyimine Etkisi & $\begin{array}{l}\text { Dokuz Eylül } \\
\text { Üniversitesi }\end{array}$ & 2018 \\
\hline Çevrimkaya & $\begin{array}{l}\text { Turist Rehberlerinin Performansının Turistin Memnuniyet } \\
\text { Düzeyine Etkisi }\end{array}$ & $\begin{array}{c}\text { Gazi } \\
\text { Üniversitesi }\end{array}$ & 2019 \\
\hline Bozbaş & $\begin{array}{l}\text { Turist Rehberlerinin Demografik ve Mesleki Değişkenler } \\
\text { Bakımından İş ve Yaşam Doyumlarının İncelenmesi }\end{array}$ & $\begin{array}{c}\text { Alanya } \\
\text { Alaaddin } \\
\text { Keykubat } \\
\text { Üniversitesi }\end{array}$ & 2019 \\
\hline Özsoy & $\begin{array}{l}\text { Profesyonel Turist Rehberlerinin Kişilik Özelliklerinin } \\
\text { Algılanan Hizmet Kalitesi Üzerindeki Rolü }\end{array}$ & $\begin{array}{l}\text { Ankara Haci } \\
\text { Bayram Veli } \\
\text { Üniversitesi }\end{array}$ & 2019 \\
\hline
\end{tabular}




\begin{tabular}{|c|c|c|c|}
\hline Narinoğlu & $\begin{array}{l}\text { Turist Rehberlerinin Türkiye'nin İmajı ve } \\
\text { Pazarlamasındaki Etkileri: Yabancı Turistler Üzerine Bir } \\
\text { Araştırma: Malezya Örneği }\end{array}$ & $\begin{array}{l}\text { Beykent } \\
\text { Üniversitesi }\end{array}$ & 2019 \\
\hline Zorkirişci & Turist Rehberlerinin Mizah Tarzları Üzerine Bir Araştırma & $\begin{array}{l}\text { Mersin } \\
\text { Üniversitesi }\end{array}$ & 2019 \\
\hline Deniz & $\begin{array}{l}\text { Profesyonel Turist Rehberlerinin Kültürel Mirasın } \\
\text { Korunmasındaki Rolü: Türkiye'deki Turist Rehberleri } \\
\text { Üzerine Bir Araştırma }\end{array}$ & $\begin{array}{l}\text { Batman } \\
\text { Üniversitesi }\end{array}$ & 2019 \\
\hline Çokal & $\begin{array}{l}\text { Turist Rehberlerinin Performansının Destinasyon İmajına } \\
\text { Etkisinde Etik Davranışlarının Düzenleyici Rolü: Nevşehir } \\
\text { Örneği }\end{array}$ & $\begin{array}{l}\text { Nevşehir Hacı } \\
\text { Bektaş Veli } \\
\text { Üniversitesi }\end{array}$ & 2019 \\
\hline Taş & $\begin{array}{l}\text { Lisans Düzeyinde Turizm Rehberliği Eğitiminde Mesleki } \\
\text { İngilizce Dersine Yönelik Bir Değerlendirme }\end{array}$ & $\begin{array}{l}\text { Ege } \\
\text { Üniversitesi }\end{array}$ & 2019 \\
\hline Kilıçhan & $\begin{array}{l}\text { Profesyonel Turist Rehberliği Mesleği: Mevcut Durum, } \\
\text { Meslek Sorunlarının Tespiti ve Çözüm Önerileri }\end{array}$ & $\begin{array}{l}\text { Erciyes } \\
\text { Üniversitesi }\end{array}$ & 2019 \\
\hline Bilgimöz & $\begin{array}{l}\text { Rekreasyonel Turizm Faaliyetlerinde Turist Rehberliği } \\
\text { Hizmetlerine İlişkin Bir Değerlendirme: Paket Tur Örneği }\end{array}$ & $\begin{array}{c}\text { Gazi } \\
\text { Üniversitesi }\end{array}$ & 2019 \\
\hline Timur & $\begin{array}{l}\text { Turist Rehberliği Eğitiminde Memnuniyet, Mesleki } \\
\text { Yeterlilik ve Mesleği İcra Niyeti İlişkileri }\end{array}$ & $\begin{array}{l}\text { Eskişehir } \\
\text { Osmangazi } \\
\text { Üniversitesi }\end{array}$ & 2019 \\
\hline Korkmaz & $\begin{array}{l}\text { Turist Rehberliği Uygulama Gezisi Üzerine } \\
\text { Karşılaştırmalı Bir Araştırma }\end{array}$ & $\begin{array}{l}\text { Ege } \\
\text { Üniversitesi }\end{array}$ & 2019 \\
\hline Kara & $\begin{array}{l}\text { Profesyonel Turist Rehberlerinin Davranış ve Mesleki } \\
\text { Yeterliliklerinin Tur Kalitesine Etkisi }\end{array}$ & $\begin{array}{l}\text { Süleyman } \\
\text { Demirel } \\
\text { Üniversitesi }\end{array}$ & 2019 \\
\hline Bektaş & $\begin{array}{l}\text { Profesyonel Turist Rehberlerinin Hizmet Verme } \\
\text { Yatkınlığının, Ziyaretçi Memnuniyeti ve Geleceğe } \\
\text { Yönelik Ziyaretçi Davranışı Üzerine Etkisi: Kapadokya } \\
\text { Örneği }\end{array}$ & $\begin{array}{l}\text { Nevşehir Hacı } \\
\text { Bektaş Veli } \\
\text { Üniversitesi }\end{array}$ & 2019 \\
\hline Gürsoy & $\begin{array}{l}\text { Profesyonel Turist Rehberlerinin Kişisel Gelişimi ve } \\
\text { Mesleki Donanımı Üzerine Bir Araştırma }\end{array}$ & $\begin{array}{l}\text { Balıkesir } \\
\text { Üniversitesi }\end{array}$ & 2019 \\
\hline
\end{tabular}

\section{YÖNTEM}

Çalışmanın bu bölümünde gerçekleştirilen araştırmanın odak noktası, amaç ve önemi ve araştırmanın yöntemi gibi konulardan bahsedilmektedir.

\subsection{Araştırmanın Amacı ve Önemi}

Turizm endüstrisinin son yıllarda tanık olduğu nicel artış turizm rehberliği alanının da gelişmesine katkıda bulunmuştur. Turist memnuniyeti ve üstlendiği kültür elçiliği gibi roller turizm rehberliği mesleğinin önemini belirtmektedir. Bu noktada devletler turizm rehberliği alanının önemi doğrultusunda turizm rehberliği eğitimine odaklanmaktadır. Türkiye'de ön lisans, lisans ve yüksek lisans düzeyinde turizm rehberliği alanında eğitim verilmektedir. Turizm rehberliği eğitiminin son dönemlerde lisansüstü düzeyde daha yaygınlaşması nedeniyle araştırma turizm rehberliği alanında yayınlanan lisansüstü tezlere yönelmiştir. 
Araştırma, Ulusal Tez Merkezi veri tabanında yer alan turist rehberliği alanındaki lisansüstü çalışmaların bibliyometrik çerçevede incelenmesi hedeflenmektedir. Bu kapsamda, turizm rehberliği alanının gelişim sürecinin ve alana yönelik çalışmaların kavramsal olarak incelenmesi ve bu doğrultuda daha sonra gerçekleştirilecek çalışmalara 1şık tutacak bir kaynak oluşturulması amaçlanmaktadır. Böylelikle lisansüstü tezlerin hangi konular üzerinde ve ne zaman yoğunlaştığı, hangi üniversitelerde ve anabilim dallarında daha çok araştırma olduğu, geçmiş ve günümüz arasında farklılık olup olmadığının bilinmesi araştırmanın önemini arz etmektedir.

\subsection{Araştırmanın Yöntemi Ve Kısıtları}

$\mathrm{Bu}$ çalışma nitel bir teknik olarak bibliyometrik analizden yararlanmaktadır. Araştırma verileri nitel araştırma örneklemlerinden ölçüt örneklem ile belirlenen anahtar kelimelerden yola çıkarak elde edilmiştir (Chandra ve Shang 2019: 38). Araştırmanın odak noktası Yükseköğretim Kurumu Ulusal Tez Merkezi (YÖKTEZ) veri tabanında yer alan turist rehberliği alanında yayımlanan lisansüstü tezlerin bibliyometrik analiz tekniğiyle irdelenmesidir. Bu kapsamda çalışma 1989 ile 2019 yılları arasında turizm rehberliği alanında yayımlanmış lisansüstü tezlere odaklanmıştır. Çalışmada kapsamda 30 yıllık dönemde gerçekleştirilmiş lisansüstü tezlere ulaşmak adına YÖK tez tarama sayfasında "turist rehberliği, turist rehberlerinin, turizm rehberliği” gibi ölçütlerde arama yapılmış ve 87 lisansüstü teze ulaşılmıştır. Bu kapsamda araştırmaların bibliyometrik açıdan özelliklerinin incelenmesi için "tezin konusu, tez türü, yayınlandığı yıl, yayınladığı üniversite, yayınlandığ1 enstitü, danışmanın ünvanı" gibi ölçütler dikkate alınmıştır. Elde edilen veriler neticesinde turist rehberliği alanında gerçekleştirilen lisansüstü tezlerin çeşitli konularda derinlemesine analizi gerçekleştirilmiş ve elde edilen bulgular yorumlanmıştır.

Bu kapsamda çalışmada cevap aranan sorular şu şekildedir:

$>$ Turizm rehberliği alanında yayımlanan lisansüstü tezlerin yıllar itibariyle dağılımı nasildir?

$>$ Turizm rehberliği alanında yayımlanan lisansüstü tezlerin üniversitelere göre dağılımı nasildir?

$>$ Turizm rehberliği alanında yayımlanan lisansüstü tezlerin enstitülere göre dağılımı nasildir?

$>$ Turizm rehberliği alanında yayımlanan lisansüstü tezlerin anabilim dallarına göre dağılımı nasıldır?

$>$ Turizm rehberliği alanında yayımlanan lisansüstü tezlerin konulara göre dağılımı nasildir?

$>$ Turizm rehberliği alanında yayımlanan lisansüstü tezlerin danışmanlık unvanlarına göre dağılımı nasıldır?

Hemen her çalışmada olduğu gibi bu araştırmanın da bazı kısıtları bulunmaktadır. Araştırma YÖKTEZ'de yer alan kısıtlı sayıdaki turizm rehberliği alanındaki lisansüstü çalışma ile sınırlandırılmıştır. Araştırma turizm yazını 1şığında sadece turizm rehberliği alanına odaklanmıştır.

\section{BULGULAR}

$\mathrm{Bu}$ araştırma turizm rehberliği alanında gerçekleştirilen lisansüstü tezlerin bibliyometrik çerçevesini tespit etmek amacıyla gerçekleştirilmiştir. Çalışma kapsamında YÖKTEZ'den 
elde edilen 87 lisansüstü tezin ilk olarak türlerine göre dağılımı incelenmiştir. Bu noktada elde edilen lisansüstü tezlerin 74'ü yüksek lisans ve 13'ü doktora şeklinde olduğu görülmektedir (Şekil 1). Yüksek lisans tezlerinin nicel olarak daha fazla olması turizm rehberliği alanına ilişkin lisansüstü çalışmaların son yıllarda yaygınlaşmasıyla açıklanabilir.

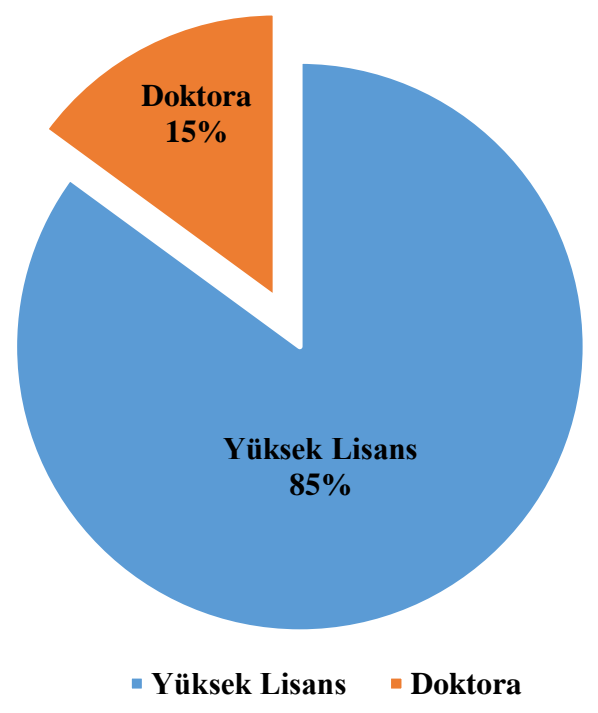

Şekil 1. Tezlerin Türlere Göre Dağılım Oranları

Tezlerin değerlendirildiği bir diğer parametre ise enstitülere göre dağılımıdır. Bu kapsamda turizm rehberliği alanında yayımlanan lisansüstü tezlerin en çok Sosyal Bilimler Enstitüsünde (82) yayımlandığı görülmektedir. Bu durum turizmin sosyal bilimler içerisinde yer alan bir alt disiplin olmasıyla ilişkilendirilebilir. Öte yandan Fen bilimleri (1) ve Eğitim bilimleri (4) alanında da yayımlanan turizm rehberliği alanına ilişkin lisansüstü tez olduğu görülmektedir (Tablo 2). Bu noktada turizmin kompleks yapısı gereği diğer bilimlerle olan ilişkisinin turizm rehberliği alanında da söz konusu olduğu söylenebilir.

Tablo 2. Tezlerin Enstitülere Göre Dağılımı

\begin{tabular}{l|ll}
\hline Enstitü & $N$ & $\%$ \\
\hline Ĕ̆itim Bilimleri Enstitüsü̈ & 4 & 5 \\
Sosyal Bilimler Enstitüsü & 82 & 94 \\
Fen Bilimleri Enstitüsü̈ & 1 & 1 \\
Toplam & $\mathbf{8 7}$ & $\mathbf{1 0 0}$ \\
\hline
\end{tabular}

Turizm rehberliği alanında yayımlanmış lisansüstü tezler, danışman unvanlarına göre değerlendirildiğinde en çok Doktor öğretim üyeleri (33) öne çıkmaktadır. Sırasıyla Doçent ve Profesör Doktorların danışmanlık yaptığı tezler ise (31) ve (23) şeklindedir. Bu kapsamda daha çok yüksek lisans tezinin yazılması ile danışmanlık açısından doktor öğretim üyesi arasında ilişki olduğu düşünülebilir. 


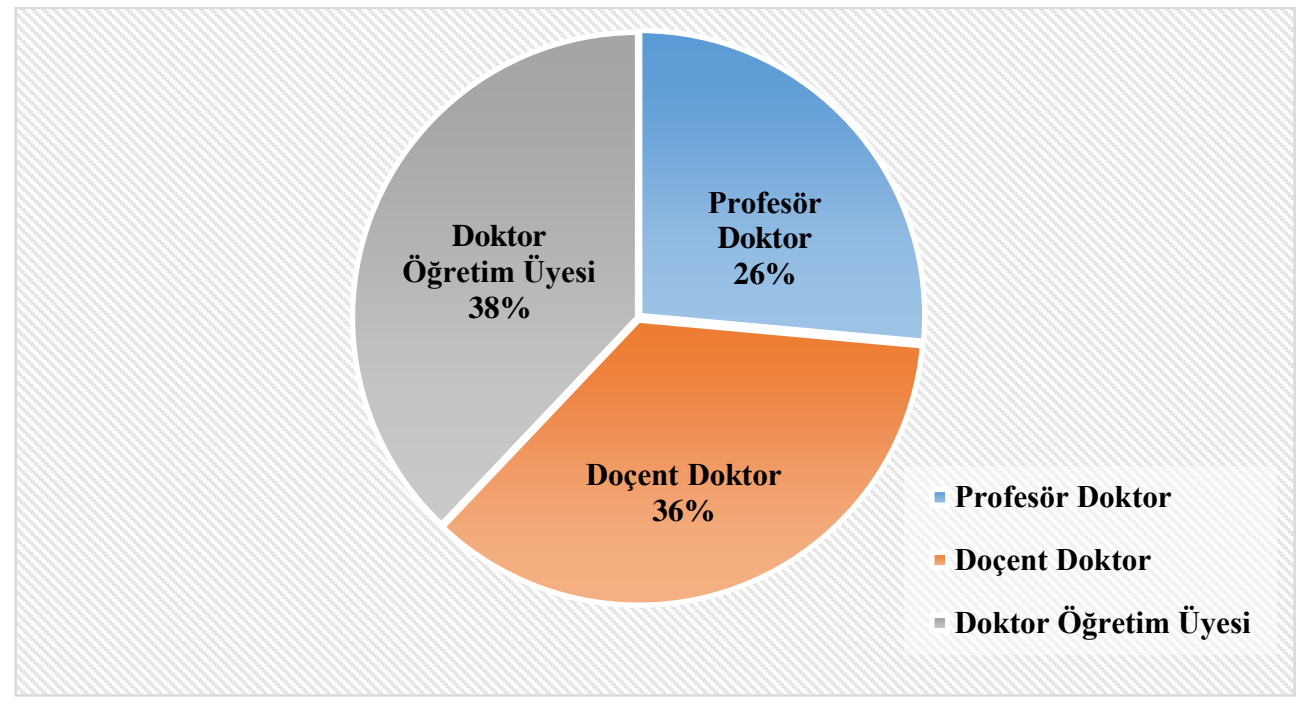

Şekil 2. Lisansüstü Tezlerin Danışman Unvanlarına Göre Dağılımı

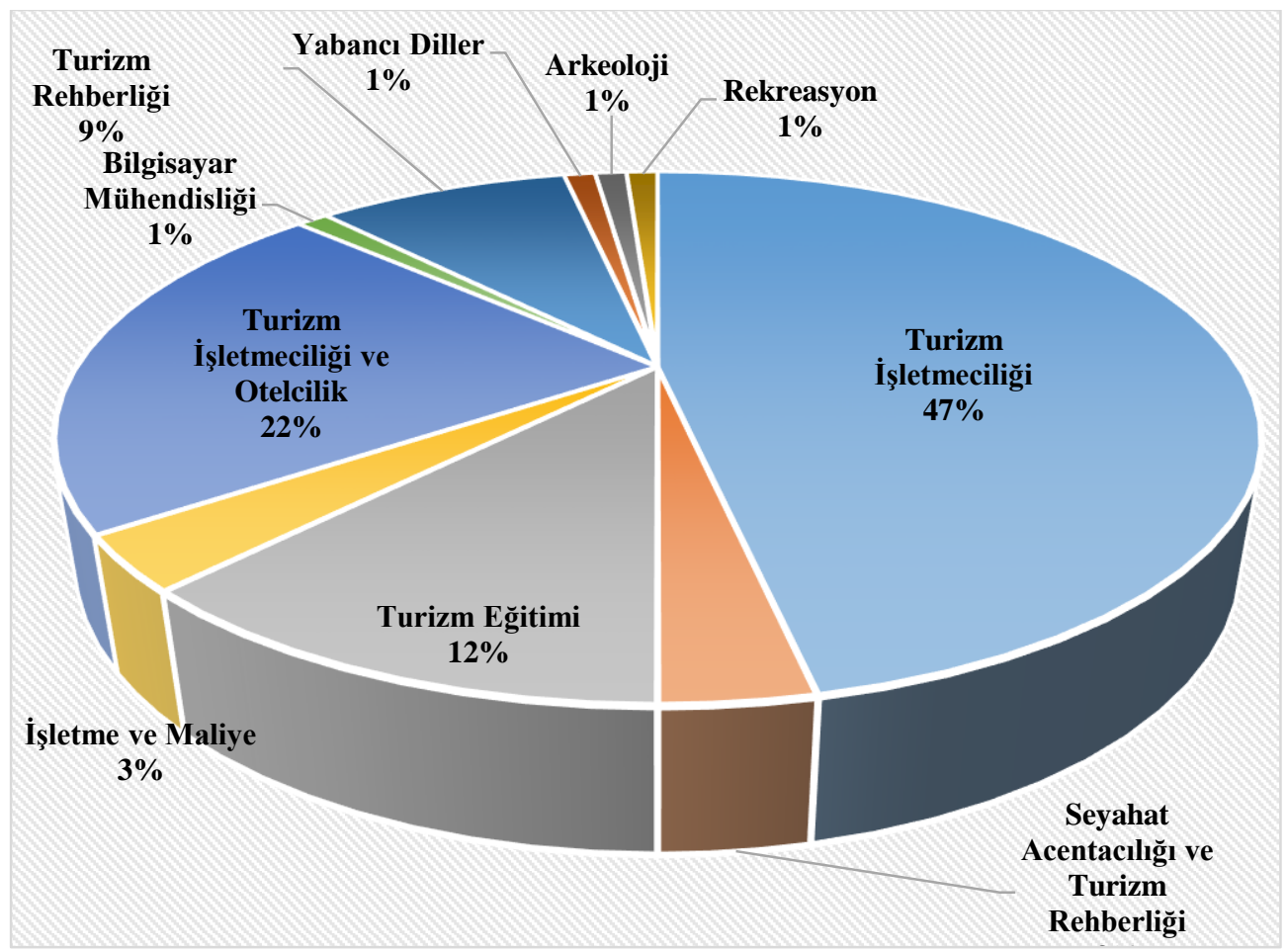

Şekil 3. Lisansüstü Tezlerin Anabilim Dallarına Göre Dağılımı 
Turizm rehberliği alanında yayımlanan lisansüstü tezlerin anabilim dalları incelendiğinde en çok Turizm İşletmeciliği Anabilim Dalında (\%47) yayımlandığı görülmektedir. Diğer taraftan ikinci sırada turizm işletmeciliği ve otelcilik anabilim dalı (\%22) gelmektedir. Turizm rehberliği sosyal bilimler içerisinde yer almasına rağmen Bilgisayar Mühendisliği gibi farklı alanında turizm rehberliğine ilişkin yazılan tezler görülmektedir. Bu durumun turizmin multidisipliner yapısından kaynaklandığı söylenebilir.

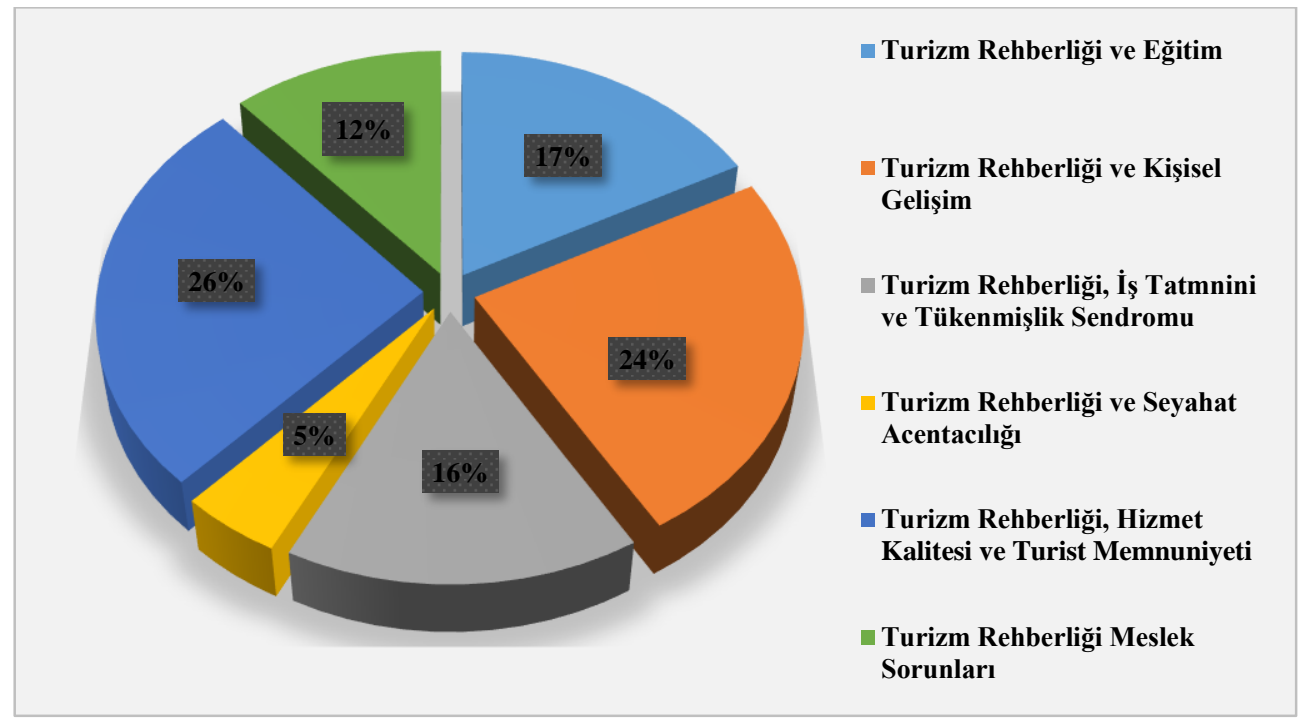

Şekil 4. Lisansüstü Tezlerin Konulara Göre Dağılımı

Lisansüstü tezler değerlendirilirken başvurulan bir diğer parametre ise tezlerin konuları olmuştur. 74 yüksek lisans ve 13 doktora tezi YÖKTEZ'den elde etmek suretiyle incelenerek konu başlıkları kategorilere ayrılmıştır. Bu kapsamda yayımlanan tezlerin en çok turizm rehberliği, hizmet kalitesi ve turist memnuniyeti (\%26) konularıla ilgili olduğu öte yandan yakın bir oranla turizm rehberliği ve kişisel gelişim (\%24) konusunun en fazla üzerinde durulan unsur olduğu görülmektedir.

Turizm rehberliği alanındaki lisansüstü tezlerin Üniversitelere göre dağılımı ele alındığında en fazla tezin Balıkesir Üniversitesinde (16) yayımlandığı görülmektedir. Diğer taraftan araştırma kapsamında elde edilen lisansüstü tezlerde Nevşehir Hacı Bektaş Veli Üniversitesi (9), Gazi ve Akdeniz Üniversiteleri ise (6)'şar tez ile turizm rehberliği yazınına katkıda bulunmuştur (Tablo 3). Çalışma ulaştığı bu bulgular ile Çapar, Toksöz ve Dönmez (2018) tarafından gerçekleştirilen araştırmayla paralellik göstermektedir.

Tablo 3. Lisansüstü Tezlerin Üniversitelere Göre Dağılımı

\begin{tabular}{l|c|l|c}
\hline Üniversite & N & Üniversite & N \\
\hline Adnan Menderes Üniversitesi & 3 & Gazi Üniversitesi & 6 \\
\hline Afyon Kocatepe Üniversitesi & 1 & Gaziantep Üniversitesi & 1 \\
\hline Akdeniz Üniversitesi & 6 & Hacettepe Üniversitesi & 2 \\
\hline Alanya Alaaddin Keykubat Üniversitesi & 1 & İstanbul Üniversitesi & 2 \\
\hline Anadolu Üniversitesi & 5 & İzmir Kâtip Çelebi Üniversitesi & 2 \\
\hline Ankara Hac1 Bayram Veli Üniversitesi & 1 & Kafkas Üniversitesi & 1 \\
\hline
\end{tabular}




\begin{tabular}{l|c|l|c}
\hline Atatürk Üniversitesi & 2 & Kastamonu Üniversitesi & 1 \\
\hline Balıkesir Üniversitesi & 16 & Kırklareli Üniversitesi & 2 \\
\hline Batman Üniversitesi & 1 & Mersin Üniversitesi & 7 \\
\hline Beykent Üniversitesi & 1 & Mustafa Kemal Üniversitesi & 1 \\
\hline Boğaziçi Üniversitesi & 1 & Nevşehir Hacı Bektaş Veli Üniversitesi & 9 \\
\hline Dokuz Eylül Üniversitesi & 2 & Sakarya Üniversitesi & 2 \\
\hline Ege Üniversitesi & 3 & Selçuk Üniversitesi & 2 \\
\hline Erciyes Üniversitesi & 2 & Süleyman Demirel Üniversitesi & 1 \\
\hline Eskişehir Osmangazi Üniversitesi & 2 & Yüzüncü Yıl Üniversitesi & 1 \\
\hline & & Toplam & $\mathbf{8 7}$ \\
\hline
\end{tabular}

Kaynak: YÖKTEZ'den araştırma kapsamında derlenmiştir.

Yıllara göre dağılım göz önüne alındığında 2000'den önce sadece 2 lisansüstü tezin olduğu ve ilk turizm rehberliğine ilişkin tezin 1989 yılında yayımlandığ 1 görülmektedir. Diğer taraftan 2018 yılında 14, 2019 yılında 13 ve 2015 yılında 14 adet tezin yayımlanmış olması son yıllarda turizm rehberliğine ilişkin lisansüstü araştırmaların yaygınlaştı̆̆ı görüşünü öne çıkarmaktadır. Araştırma bu noktada Özsoy ve Çokal'ın (2018) yaptığı çalışma ile benzerlik göstermektedir.

Tablo 4. Lisansüstü Tezlerin Yıllara Göre Dağılımı

\begin{tabular}{cccc}
\hline Yll & N & Yll & N \\
\hline 1989 & 1 & 2010 & 3 \\
\hline 1998 & 1 & 2011 & 1 \\
\hline 2001 & 1 & 2012 & 4 \\
\hline 2002 & 1 & 2013 & 2 \\
\hline 2003 & 2 & 2014 & 14 \\
\hline 2004 & 1 & 2015 & 9 \\
\hline 2005 & 2 & 2016 & 9 \\
\hline 2006 & 3 & 2017 & 14 \\
\hline 2007 & 3 & 2018 & - \\
\hline 2008 & 1 & 2019 & $\mathbf{8 7}$ \\
\hline 2009 & 1 & - & \\
\hline & & Toplam &
\end{tabular}

Kaynak: YÖKTEZ'den araştırma kapsamında derlenmiştir.

\section{DEĞERLENDIRME VE SONUÇ}

$\mathrm{Bu}$ araştırma kapsamında YÖKTEZ veri tabanında 1989-2019 yılları arasında 30 yıllık dönemde turizm rehberliği alanındaki yayımlanmış 74 yüksek lisans ve 13 doktora tezi bazı ölçütler çerçevesinde incelenmiştir. Araştırma kapsamında en çok lisansüstü tezin Balıkesir Üniversitesi SBE tarafından yayımlandığı tespit edilmiştir. Öte yandan sırasıyla Nevşehir Hacı Bektaş Veli, Gazi ve Akdeniz Üniversiteleri turizm rehberliği alanına katkı sağlayan önemli üniversiteler arasında olduğu görülmektedir. Lisansüstü tezlerin yıllara göre dağılımı kapsamında 2015-2019 yılları arasında büyük bir artışın olduğu dikkat çekmektedir. Bu kapsamda yeni açılan turizm ve turizm rehberliği lisansüstü programlarının son yıllardaki radikal artışın arka planını oluşturduğu söylenebilir.

Turizm rehberliği alanındaki lisansüstü tezlerin en çok yüksek lisans düzeyinde ve doktor öğretim üyeleri tarafından yönetildiği tespit edilmiştir. Bir diğer elde edilen bulgu ise turizm rehberliği alanında yayımlanan lisansüstü tezlerin en çok Sosyal Bilimler Enstitüsü'nde ve Turizm İşletmeciliği Anabilim Dalında gerçekleştirildiğidir. Bu durum turizmin sosyal 
bilimlere ait bir disiplin olmasıyla izah edilebilir. Ayrıca mühendislik alanında da turizm rehberliğine ilişkin tez olduğu varılan bir diğer önemli bulgudur. Araştırma bu bulgularıyla Özsoy ve Çokal (2018) ile benzerlik göstermekte ancak Seyahat Acentacılığı ve Turizm Rehberliği Anabilim Dalı ile Turizm Rehberliği Anabilim Dalı'ında yayımlanan tezlere ulaşması bakımından çalışma farklılık göstermektedir. Araştırmanın diğer parametresi oluşturan konular ele alındığında en çok Turizm Rehberliği, Hizmet Kalitesi ve Turist Memnuniyeti, Turizm Rehberliği ile Kişisel Gelişim konuları üzerinde durulduğu sonucuna ulaşılmıştır. Bu kapsamda turizm rehberliği alanında yapılan tezlerin çeşitlendiği söylenebilir.

Araştırmanın sadece Türkiye'de yayınlanmış lisansüstü tezlere yönelmesi bazı kısıtlara neden olmuştur. İlerideki çalışmalar turizm rehberliği alanındaki yabancı tezleri de kapsayacak şekilde genişletilebilir. AB ve benzeri turizm açısından gelişmiş ülkeler ile de kıyaslama yapılabilir. Öte yandan gelecekte yapılacak bibliyometrik araştırmalar, turizm ve rehberlik alanındaki kongrelerde sunulan turizm rehberliğine ilişkin bildirilerin konu, içerik, yöntem ve bulgu kapsamında değerlendirilmesi şeklinde olabilir. Bu noktada turizm rehberliği yazınının gelişim dönemleri lisansüstü araştırmalar, bildiri ve makaleler açısından karşılaştırılıp, benzerlik ve farklılıkları incelenebilir.

\section{KAYNAKÇA}

AKKAŞOĞLU, S., AKYOL, C., ULAMA, Ş., \& ZENGIN B. (2019). Tarım Turizmine Yönelik Hazırlanan Lisansüstü Tezlerin Bibliyometrik Analizi. Journal of Tourism and Gastronomy Studies, 7 (2), 1193-1218.

BAYRAM ERKOL, G., \& ZENGIN, B. (2017). Turist Rehberlerinin Verimliliğini Etkileyen Psikolojikı Faktörler (Ö. Güzel, V. Altıntaş, \& İ. Şahin, Eds.). Ankara: Detay Yayıncilik.

ÇAKMAK, T., \& DEMİRKOL, Ş. (2017). Teknolojik Gelişmelerin Turist Rehberliği Mesleğine Etkileri Üzerine Bir Swot Analizi. Bingöl Üniversitesi Sosyal Bilimler Enstitüsü Dergisi, 221-235. https://doi.org/10.29029/ busbed.317656

ÇAPAR, G., TOKSÖZ, D., \& DÖNMEZ B. (2018). Turizm Rehberliği Alanında Yapılan Akademik Çalışmaların İncelenmesi. Journal of Tour Guiding, 1 (2), 57-73.

ÇETIN, G., \& KIZILIRMAK, İ. (2017). Türk Turizminde Kokartlı Turist Rehberlerin Mevcut Durumunun Analizi. Seyahat ve Otel İşletmeciliği Dergisi, 14 (2), 142-156. Retrieved from http://hdl.handle.net/11630/1494

CHANDRA, Y., \& SHANG, L. (2019). Qualitative Research Using R: A Systematic Approach. Springer. https://doi.org/10.1007/978-981-13-3170-1

COHEN, E. (1985). The Tourist Guide: The Origins, Structure and Dynamics of a Role. Annals of Tourism Research, 12 (1), 5-29.

ÇOKAL, Z., \& ASLAN, Z. (2016). Profesyonel Turist Rehberinin Kültürel Değerlere Katkısına İlişkin Turist Algılamaları (Tourists Perception of Professional Tourist Guide s Contribution to Cultural Values). Journal of Tourism and Gastronomy Studies, 4 (1), 53-53. https://doi.org/10.21325/jotags.2016.6

EKER, N., KAYA, C., \& ZENGİN, B. (2019). Turist Rehberliği Mesleği (Dünü- BugünüYarın) (B. Zengin, G. E, Bayram, \& O. Batman, Eds.). Ankara. 
EKER N., \& ZENGİN, B. (2016). Turizm Rehberliği Eğitimi Müfredatlarının Uygulama Yeterliliğinin Profesyonel Turist Rehberleri Bakış Açısıyla İrdelenmesi. Turizm ve Arastırma Dergisi, 5 (2).

GÜDÜ DEMIRBULAT, Ö., \& TETIK DİNÇ, N. (2017). Sürdürülebilir Turizm Konulu Lisansüstü Tezlerin Bibliyometrik Profili. Seyahat ve Otel İşletmeciliği Dergisi, 14 (2), 20-30. https://doi.org/10.24010/soid.334320

GÜLLÜ K., \& ATASOY, B. (2019). Gastronomi Turistlerinin Destinasyon Tercihini Etkileyen Motivasyon Faktörlerinin İncelenmesi. In O. Emir (Ed.), 20. Ulusal Turizm Kongresi (pp. 799-806). https://doi.org/978-975-06-3632-5 Anadolu Üniversitesi Basımevi Ekim

KAYA, U., \& ÖZHAN, Ç. (2012). Duygusal Emek ve Tükenmişlik İlişkisi: Turist Rehberleri Üzerine Bir Araştırma. Çalışma İlişkileri Dergisi, 3 (2), 109-130.

LOVRENTJEV, S. (2015). Education of Tourist Guides: Case of Croatia. Procedia Economics and Finance, 23(October 2014), 555-562. https://doi.org/ 10.1016/s22125671(15)00538-9

OLCAY, A., \& AKKÖZ, H. (2014). Profesyonel Turist Rehberlerinin Performanslarının Yerli Turistler Tarafindan Değerlendirilmesi. Journal of Businesss Research Turk, 7 (2), 349-374.

ÖZEL, Ç., \& KOZAK, N. (2012). Turizm Pazarlaması Alanının Bibliyometrik Profili ve Bir Atıf Analizi. Türk Kütüphaneceliiği, 26 (4), 715-733.

ÖZSOY, A., \& ÇOKAL, Z. (2018b). Türkiye'de Turist Rehberliği Alanında Yayımlanmış Lisansüstü Tezlerin Bibliyometrik Analizi (1989-2018). 2nd International EMI Entrepreneurship \& Social Sciences Congress, 09-11 November 2018, Cappadocia, (November 2018).

REISINGER, Y., \& STEINER, C. (2006). Reconceptualising İterpretation: The Role of Tour Guides in Authentic Tourism. Current Issues in Tourism, 9 (6), 481-498.

https://doi.org/10.2167/cit280.0

ŞAHIN, S., \& ACUN, A. (2015). Turist Rehberliği Alanının Bibliyometrik Profili. Balıkesir University The Journal of Social Sciences Institute, 18 (34), 213-234.

SARIIŞIK, M., \& ÖZBAY, G. (2015). Gastronomi Turizmi Üzerine Bir Literatür İncelemesi. Anatolia Turizm Araştırmaları Dergisi, 26 (2), 264-278. https://doi.org/10.17123/atad. vol26iss 218417

SERT, A. N., \& KARACAOĞLU, S. (2018). Turist Rehberlerinin Mesleki Sorunları Üzerine Bir Araştırma: Kapadokya Örneği (A Study on Problems of Tour Guides: The Case of Cappadocia). Journal of Tourism and Gastronomy Studies, 6 (3), 81-99. https://doi.org/10.21325/jotags.2018.273

TUREB, Turist Rehberleri Birliği. (2014). Retrieved November 8, 2019, from http://www.tureb.org.tr/tr/Page/Detail/62 
WFTGA. (2003). What is a Tourist Guide? | World Federation of Tourist Guide Associations. Retrieved November 8, 2019, from http://wftga.org/tourist-guiding/what-tourist-guide

YENIPINAR, U., \& ZORKİIŞ̧ÇI, A. (2013). Türkiye ve Avrupa Birliği Ülkelerinde Turist Rehberliği Eğitimi, Cag University Journal of Social Sciences, 10 (2), 111-136.

YENIPINAR ,U., BAK, E., \& ÇAPAR, G. (2014). Turist Rehberliği Meslek Kanununun, Meslek Örgütleri ve Öğretim Elemanlarının Bakış Açısı ile Değerlendirilmesi. Çă̆ Üniversitesi Sosyal Bilimler Dergisi, 11 (2), 86-114. Retrieved from https://dergipark.org.tr/cagsbd/ issue/44631/554447 